\title{
Australian Summer Monsoon variability in the past 14,000 years revealed by IODP Expedition 356 sediments
}

Takeshige Ishiwa ${ }^{1,2,3^{*}}$ D, Yusuke Yokoyama ${ }^{2,3}$, Lars Reuning ${ }^{4,8}$, Cecilia M. McHugh5 ${ }^{5}$, David De Vleeschouwer ${ }^{6}$ and Stephen J. Gallagher ${ }^{7}$

\begin{abstract}
The International Ocean Discovery Program (IODP) Expedition 356 Site U1461 cored a Miocene to Holocene sedimentary sequence in the upper bathyal carbonate offshore northwestern Australia (NWA). The siliciclastic component of these strata is primarily derived from the Australian continent. Radiocarbon dating on macrofossils and planktonic foraminifera shows that the upper $14 \mathrm{~m}$ section at Site U1461 preserves Holocene sediments, recording regional climate variability. K/Ca ratios determined by X-ray fluorescence elemental analyses and \%K determined by shipboard natural gamma ray analysis are interpreted as indicators of riverine run-off from the Australian continent. We document the consequences of the variability of the Australian Summer Monsoon (ASM) on the continental shelf of NWA. We report an increase in terrigenous input due to a riverine run-off after $11.5 \mathrm{ka}$, which reaches a maximum at $\sim 8.5 \mathrm{ka}$. This maximum is the result of the enhanced ASM-derived precipitation in response to the southern migration of the Intertropical Convergence Zone (ITCZ). A decrease in riverine run-off due to a weakening of precipitation in the NWA region after $8.5 \mathrm{ka}$ was caused by the northern migration of the ITCZ. We conclude that the ITCZ reached its southernmost position at $8.5 \mathrm{ka}$ and enhanced precipitation in the NWA region. This Holocene record shows that even during interglacial periods, monsoonal variability was primarily controlled by the position of the ITCZ.
\end{abstract}

Keywords: International Ocean Discovery Program Expedition 356, Australian Summer Monsoon, Radiocarbon dating, Holocene climate variability, Northwestern Australia

\section{Introduction}

Northwestern Australia (NWA) is located at the edge of the Indo-Pacific Warm Pool (IPWP), which is the largest source of moisture and heat on Earth (Gagan et al. 2004; De Deckker et al. 2014; De Deckker 2016). NWA shelf underlies the path of the Leeuwin Current, a regional south-flowing current and branch of the Indonesian Throughflow, which brings warm and low salinity water from the IPWP to the Indian Ocean (Gallagher et al. 2009, 2014). A strong rainfall seasonality characterizes NWA climate variability during the Australian Summer Monsoon (ASM), which is one of the largest monsoons

\footnotetext{
* Correspondence: ishiwa.takeshige@nipr.ac.jp

${ }^{1}$ National Institute of Polar Research, Tokyo, Japan

${ }^{2}$ Atmosphere and Ocean Research Institute, The University of Tokyo, Chiba, Japan

Full list of author information is available at the end of the article
}

similar to the Indian Monsoon (Betzler et al. 2017) and the Asian Monsoon (Wang et al. 2001; Tada et al. 2016). ASM rainfall plays an important role for the hydrology of the equatorial Pacific and Indian Ocean through the Indonesian archipelago deriving freshwater discharge from rivers and changing water salinity in this region (De Deckker 2016). During glacial-interglacial cycles, the intensity of the ASM changed on 100-1000-year time scales (Kuhnt et al. 2015; Eroglu et al. 2016). The ASM is strongly influenced by the position of the Intertropical Convergence Zone (ITCZ), which migrated with warming and cooling conditions during the deglaciation period (Kuhnt et al. 2015; Mohtadi et al. 2011). Indonesian stalagmite $\delta^{18} \mathrm{O}$ data records the precipitation pattern of the ASM during the last deglaciation, suggesting that the ASM was synchronized with northern high-latitude climate events (Ayliffe et al. 2013; Denniston et al. 2013). 
Modelling studies show that the exposure of the Sunda Shelf during the Last Glacial Maximum (LGM) and its flooding during the Holocene global sea level rise have influenced the hydrological cycle in the tropical Pacific and the eastern Indian Ocean and have caused rainfall variation in NWA (Di Nezio and Tierney 2013).

Terrigenous input from riverine run-off is a key proxy for monsoonal rainfall variation in the NWA region (De Deckker et al. 2014; Gallagher et al. 2014; Kuhnt et al. 2015; Stuut et al. 2014). Previously, analyses of cores in the Timor Sea used riverine run-off as a key proxy for monsoonal rainfall to determine the relative ASM activity (Kuhnt et al. 2015). However, the source of sediment in the Timor Sea is both from distal locations of the Australian continent and the Indonesian archipelago. The International Ocean
Discovery Program (IODP) Expedition 356 Indonesian Throughflow recovered a proximal ASM terrigenous proxy record by coring a series of sites in the shallow continental shelf to the upper bathyal region part of offshore NWA (Fig. 1), recovering a sequence of Miocene to Holocene sediments at Site U1461 over $1 \mathrm{~km}$ thick (Gallagher et al. 2015, 2017a). Due to their proximity to the Australian coast, the siliciclastic component of the sediments is derived from the NWA continent via the Fortescue and De Grey rivers (Fig. 1; James et al. 2004). We date the upper $14 \mathrm{~m}$ of Site U1461 using radiocarbon dating and describe the past 14,000 years of climate variability in NWA. The strata reveal evidence of the linkage between the ASM and global climate changes, enhancing our understanding of the Holocene history of the ITCZ migration across the continental shelf of NWA.

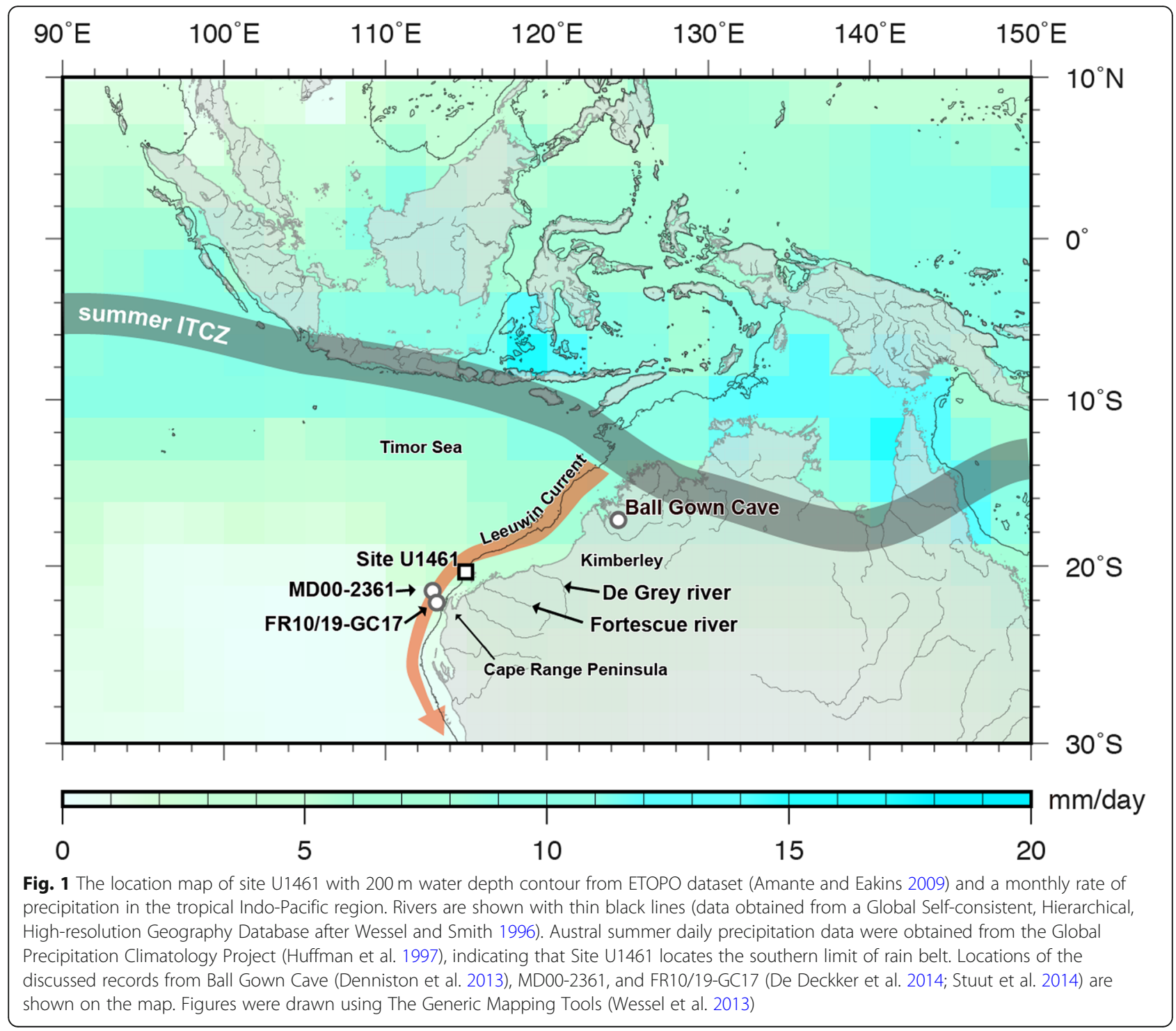




\section{Methods/Experimental}

\section{IODP Expedition 356 Site U1461}

IODP Expedition 356 Site U1461 (20 12.8634' S, $115^{\circ} 03.9495^{\prime}$ E) cored a $\sim 1 \mathrm{~km}$ thick section in 127 m water depth (Fig. 1) with $86 \%$ core recovery (Gallagher et al. 2015). This study focuses on the top $14 \mathrm{~m}$ of the core, which yielded well-preserved macrofossils (bivalves) and planktonic foraminifera for radiocarbon dating.

The upper part of Site U1461 is divided into two units: unit I and subunit IIa (Gallagher et al. 2017a). Unit I extends from the core top to $12.4 \mathrm{~m} \mathrm{CCSF-A} \mathrm{and} \mathrm{unit} \mathrm{IIa}$

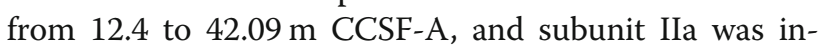
vestigated to a depth of $14.0 \mathrm{~m}$ CCSF-A for this study. Unit I is a homogeneous olive-grey to greenish grey packstone (Fig. 2) with planktonic and benthic foraminifera, sponge spicules, and aragonitic pteropod shells (Gallagher et al. 2017a). The main carbonate mineral is aragonite (average $\sim 35 \%$ of the sediment obtained from five samples in unit I) and the main non-carbonate mineral is quartz (average $\sim 27 \%$ of the sediment) based on the shipboard semi-quantitative XRD analysis (Gallagher et al. 2017a). Subunit IIa is a creamy-grey mudstone to wackestone (Fig. 2) with glauconite and abundant peloids (Gallagher et al. 2017a). Macrofossils such as bivalves, gastropods, scaphopods, pteropods, echinoderms, bryozoans, small benthic foraminifers, and solitary corals are common (Gallagher et al. 2017a). The average content of aragonite of this interval is 79\%. Quartz is rare, and clay minerals are absent in subunit IIa (Gallagher et al. 2017a).

\section{Physical properties and major elemental analysis}

Natural gamma radiation (NGR) is emitted when ${ }^{40} \mathrm{~K}$, ${ }^{232}$ Th-series, and ${ }^{238} \mathrm{U}$-series nuclides decay to their daughter isotopes. Shipboard measurements of NGR detect these emissions and provide the means to quantify the $\mathrm{K}, \mathrm{U}$, and Th contents of the recovered sediments (Gallagher et al. 2017b; De Vleeschouwer et al. 2017). In the upper part of the cored sequence considered in this study, shipboard NGR measurements were carried out at a $10 \mathrm{~cm}$ resolution in Holes $\mathrm{U} 1461 \mathrm{~B}$ and D and at a $20 \mathrm{~cm}$ resolution in Holes U1461A and C. We use the freely available MATLAB algorithms of De Vleeschouwer et al. (2017) to decompose the NGR energy spectra and quantify the $\mathrm{K}(\mathrm{wt} . \%), \mathrm{U}(\mathrm{mg} / \mathrm{kg})$, and $\mathrm{Th}(\mathrm{mg} / \mathrm{kg})$ contents (https://doi.org/10.1594/IEDA/100668).

The top $14 \mathrm{~m}$ CSF-A (equivalent to $15 \mathrm{~m} \mathrm{CCSF-A)} \mathrm{of}$ Hole U1461C was also subject to an Avaatech X-ray fluorescence (XRF) scanning at $5 \mathrm{~cm}$ intervals, which was conducted at the International Ocean Discovery Program's Gulf Coast Repository. The core sections were covered with $4 \mu \mathrm{m}$-thick ultralene, and the samples were analysed twice at $9 \mathrm{kV}$ and $30 \mathrm{kV}$. Here, we interpret only calcium (Ca), potassium (K), and titanium (Ti), which are more robust compared to lighter elements, as the latter is affected by the water content and the split-core surface (Kido et al. 2006; Ishiwa et al. 2016; Nakamura et al. 2016).

\section{Age-depth model based on radiocarbon dating}

Radiocarbon dating of macrofossils and planktonic foraminifera (Table 1) was carried out using single-stage accelerator mass spectrometry at Atmosphere and Ocean Research Institute, The University of Tokyo (Yokoyama et al. 2016). Macrofossils were etched by $10 \mathrm{M} \mathrm{HCl}$ to remove contamination and secondary carbonate (Ishiwa et al. 2016). Foraminifera were washed in an ultrasonic bath prior to graphitization. The method of graphitization follows Yokoyama et al. (2007).

Calendar ages were obtained using a Bayesian age modelling approach (Bchron: Haslett and Parnell 2008; Parnell et al. 2008) with Marine 13 (Reimer et al. 2013) as a calibration curve. We set the local reservoir correction to 0 at Site U1461, since a local reservoir correction in the NWA continental shelf was previously reported to be minor (O'Connor et al. 2010; Bowman 1985). The Bchron algorithm uses Monte Carlo methods to produce a continuous age-depth model and interpolates ages of outlier intervals using obtained ages.

\section{Results}

$\% \mathrm{~K}$ variation by natural gamma radiation analysis

The $\% \mathrm{~K}$ is $\sim 0.2 \%$ from 14.0 to $12.4 \mathrm{~m} \mathrm{CCSF-A} \mathrm{and} \mathrm{in-}$ creases to $9.6 \mathrm{~m} \mathrm{CCSF}-\mathrm{A}$. The maximum $\% \mathrm{~K}$ is $\sim 0.6 \%$ at $\sim 9.6 \mathrm{~m} \mathrm{CCSF-A.} \mathrm{Above} 9.6 \mathrm{~m} \mathrm{CCSF-A,} \mathrm{the} \mathrm{\% K} \mathrm{de-}$ creases to $0.2 \%$ to the core top (Fig. 2). The $\% \mathrm{~K}$ value at $8.31 \mathrm{~m}$ CCSF-A in Hole U1461C is interpreted to be an outlier because there was an insufficient volume of sediments in the core liner at this level.

\section{Major elemental analysis by XRF scanning}

The Ca counts are $\sim 800,000$ from 14.0 to $11.5 \mathrm{~m}$ CSSF-A and gradually decrease from 11.5 to $9.4 \mathrm{~m}$ CCSF-A. There is a marked reduction at $1.6 \mathrm{~m} \mathrm{CCSF-A}$ (Fig. 2). The K counts are $\sim 2000$ from 14.0 to $11.5 \mathrm{~m}$ CCSF-A, increasing to 10,600 counts at $10.2 \mathrm{~m} \mathrm{CCSF-A.}$ The $\mathrm{K}$ counts gradually decrease from $8.2 \mathrm{~m} \mathrm{CCSF-A} \mathrm{to}$ 4000 counts in the core top (Fig. 2). The Ti counts are $\sim 500$ from 14.0 to $12.4 \mathrm{~m}$ CCSF-A, with a marked increase to 6000 counts that occurs from 12.4 to $10.2 \mathrm{~m}$ CSF-A. The Ti counts gradually decrease to 1000 counts from $8.2 \mathrm{~m} \mathrm{CCSF-A} \mathrm{to} \mathrm{the} \mathrm{core} \mathrm{top.} \mathrm{K}$ and $\mathrm{Ti}$ counts show a similar pattern of variability through the studied interval. 


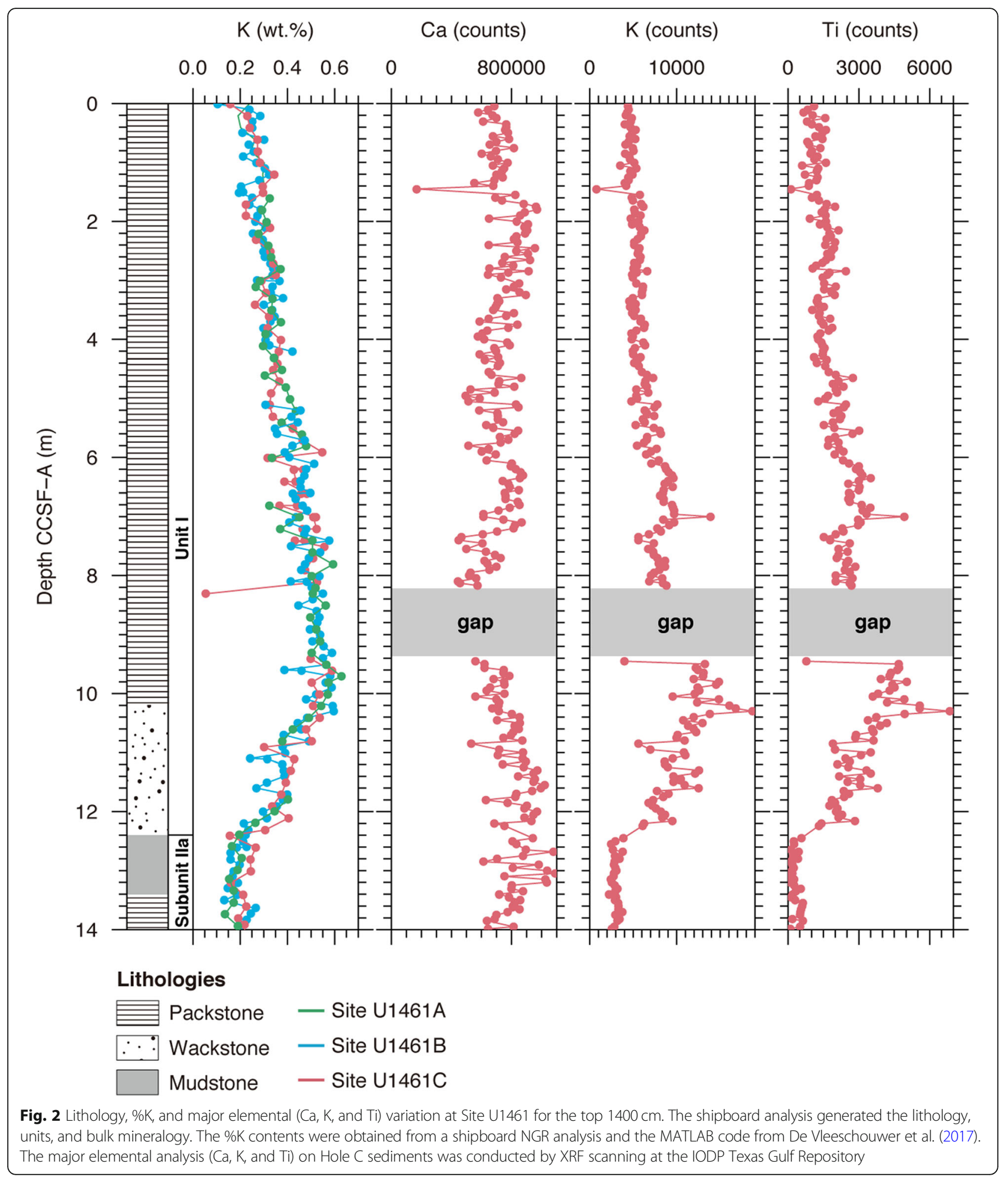

\section{Age-depth model}

Radiocarbon dating results are shown in Table 1. The age-depth model established by Bchron suggests that the interval from $15.0 \mathrm{~m}$ CCSF-A to the core top corresponds to the last 25,000 years (Fig. 3). An extremely low sedimentation rate $(\sim 0.07 \mathrm{~m} / \mathrm{kyr})$ occurred before $13.5 \mathrm{ka}$, suggesting that the past climate variability may not be recording at the accurate timing. Subsequently, relatively high sedimentation $(\sim 1.0 \mathrm{~m} / \mathrm{kyr})$ is observed to the core top. Ages obtained from foraminifera at $7.81 \mathrm{~m}$ CCSF-A 
Table 1 Age results of Site U1461

\begin{tabular}{|c|c|c|c|c|c|c|c|c|}
\hline \multirow{2}{*}{$\begin{array}{l}\text { Lab. ID } \\
\text { YAUT-034215 }\end{array}$} & \multirow{2}{*}{$\begin{array}{l}\text { Name } \\
\text { 356-U1461C-1H-1 W-9/11 }\end{array}$} & \multirow{2}{*}{$\begin{array}{l}\text { Depth } \\
\text { CSF-A (m) } \\
0.1\end{array}$} & \multirow{2}{*}{$\begin{array}{l}\text { Depth } \\
\text { CCSF-A (m) } \\
0.1\end{array}$} & \multirow{2}{*}{$\begin{array}{l}\text { Radiocarbon age } \\
\text { (year BP) }\end{array}$} & \multicolumn{4}{|c|}{$\begin{array}{l}\text { Calendar age (cal year BP) 95\% } \\
\text { highest density regions }\end{array}$} \\
\hline & & & & & 925 & 1084 & 94.2 & $\mathrm{~F}$ \\
\hline YAUT-019123 & 356-U1461A-1F-1W-80/84 & 0.82 & 0.82 & $44,530 \pm 310$ & 46,626 & 48,029 & 94.7 & $\mathrm{~F}$ \\
\hline YAUT-034216 & 356-U1461C-1H-1 W-109/111 & 1.1 & 1.1 & $2580 \pm 50$ & 2142 & 2336 & 94.3 & $\mathrm{~F}$ \\
\hline YAUT-034209 & 356-U1461A-2F-2W-90/94 & 4.02 & 4.02 & $4850 \pm 30$ & 5049 & 5257 & 94.5 & $\mathrm{~F}$ \\
\hline YAUT-034217 & 356-U1461C-1H-4 W-49/51 & 5 & 5 & $5290 \pm 30$ & 5584 & 5703 & 93.8 & $\mathrm{~F}$ \\
\hline YAUT-034211 & 356-U1461A-3F-1W-80/84 & 7.12 & 7.62 & $6830 \pm 40$ & 7284 & 7409 & 94 & $\mathrm{~F}$ \\
\hline YAUT-019119 & 356-U1461C-1H-6W-29/32 & 7.81 & 7.81 & $6020 \pm 40$ & 6334 & 6517 & 94.1 & M \\
\hline YAUT-034213 & 356-U1461B-2H-3 W-69/71 & 8.1 & 8.8 & $6950 \pm 40$ & 7406 & 7516 & 93.7 & $\mathrm{~F}$ \\
\hline YAUT-034212 & 356-U1461B-2H-3 W-109/111 & 8.5 & 9.2 & $7570 \pm 40$ & 7955 & 8119 & 94.1 & $\mathrm{~F}$ \\
\hline YAUT-034218 & 356-U1461C-2H-1 W-109/111 & 9.5 & 10.5 & $8020 \pm 40$ & 8390 & 8548 & 94.2 & $\mathrm{~F}$ \\
\hline YAUT-030602 & $356-U 1461 \mathrm{C}-2 \mathrm{H}-4 \mathrm{~A}-10 / 11$ & 13.01 & 14.01 & $11,990 \pm 50$ & 13,335 & 13,526 & 94.2 & M \\
\hline YAUT-030603 & $356-U 1461 \mathrm{C}-2 \mathrm{H}-4 \mathrm{~A}-36 / 37$ & 13.27 & 14.27 & $14,620 \pm 50$ & 17,155 & 17,458 & 94.6 & M \\
\hline YAUT-030604 & 356-U1461C-2H-4 W-38/40 & 13.29 & 14.29 & $20,470 \pm 60$ & 23,999 & 24,257 & 94.4 & M \\
\hline YAUT-030605 & $356-U 1461 \mathrm{C}-2 \mathrm{H}-4 \mathrm{~A}-40 / 41$ & 13.31 & 14.31 & $16,920 \pm 60$ & 19,786 & 20,056 & 94.4 & M \\
\hline YAUT-019120 & 356-U1461C-2H-4 W-46/52 & 13.39 & 14.39 & $20,160 \pm 60$ & 23,645 & 23,923 & 94.5 & M \\
\hline YAUT-030607 & 356-U1461C-2H-4A-99/100 & 13.90 & 14.90 & $12,130 \pm 60$ & 13,461 & 13,708 & 94.5 & M \\
\hline YAUT-030611 & 356-U1461A-4H-3A-78/79 & 14.64 & 15.42 & $48,760 \pm 770$ & - & - & - & M \\
\hline YAUT-030609 & 356-U1461B-3H-1A-62/63 & 14.53 & 15.50 & $49,300 \pm 820$ & - & - & - & M \\
\hline YAUT-030612 & 356-U1461B-3H-1 W-77/78 & 14.68 & 15.65 & $54,750 \pm 1540$ & - & - & - & M \\
\hline YAUT-030637 & 356-U1461A-4H-3A-117/118 & 15.03 & 15.81 & $49,220 \pm 830$ & - & - & - & M \\
\hline YAUT-030639 & 356-U1461B-3H-2A-3/6 & 15.45 & 16.42 & $40,980 \pm 330$ & - & - & - & M \\
\hline YAUT-030613 & $356-U 1461 C-2 H-6$ W-2/3 & 15.93 & 16.93 & $51,470 \pm 1030$ & - & - & - & M \\
\hline YAUT-030615 & 356-U1461C-2H-6 W-6/7 & 15.97 & 16.97 & $49,550 \pm 830$ & - & - & - & M \\
\hline YAUT-030617 & 356-U1461B-3H-2 W-63/64 & 16.04 & 17.01 & $41,580 \pm 370$ & - & - & - & M \\
\hline YAUT-030618 & 356-U1461B-3H-2 W-68/68 & 16.08 & 17.05 & $45,090 \pm 510$ & - & - & - & M \\
\hline YAUT-019122 & 356-U1461C-2H-7 W-54/56 & 17.55 & 18.55 & $2040 \pm 40$ & - & - & - & M \\
\hline YAUT-030621 & 356-U1461C-3H-1 W-93/94 & 18.84 & 20.63 & $57,090 \pm 1990$ & - & - & - & M \\
\hline YAUT-030624 & 356-U1461C-3H-2 W-88/90 & 20.29 & 22.08 & $42,350 \pm 450$ & - & - & - & M \\
\hline YAUT-030625 & 356-U1461A-5H-1 W-4/7 & 20.56 & 22.67 & $12,310 \pm 40$ & - & - & - & M \\
\hline YAUT-030626 & 356-U1461C-3H-3 W-120/121 & 22.11 & 23.90 & $55,830 \pm 1750$ & - & - & - & M \\
\hline YAUT-030628 & 356-U1461A-5H-3A-72/73 & 24.23 & 26.34 & $50,710 \pm 1060$ & - & - & - & M \\
\hline YAUT-030629 & 356-U1461C-3H-6 W-3/4 & 25.44 & 27.23 & $>37,964$ & - & - & - & M \\
\hline YAUT-030631 & 356-U1461C-3H-6W-29/30 & 25.70 & 27.49 & $50,330 \pm 0$ & - & - & - & M \\
\hline YAUT-019125 & 356-U1461C-4H-1 W-13/18 & 27.56 & 31.06 & $44,730 \pm 320$ & - & - & - & M \\
\hline YAUT-030632 & 356-U1461C-4H-2 W-96/97 & 29.81 & 33.31 & $>39,963$ & - & - & - & M \\
\hline YAUT-030635 & $356-U 1461 C-4 H-2 W-122 / 124$ & 30.07 & 33.57 & $>40,470$ & - & - & - & M \\
\hline YAUT-030636 & 356-U1461C-4H-3 W-60/61 & 30.95 & 34.45 & $>39,907$ & - & - & - & M \\
\hline
\end{tabular}

Calendar age is calculated using Bchron model (Haslett and Parnell 2008; Parnell et al. 2008) with a Marine 13 curve (Reimer et al. 2013 ). YAUT is a laboratory number of the single-stage accelerator mass spectrometry at the University of Tokyo

$F$ planktonic foraminifera, $M$ macrofossils

and macrofossil ages at $7.62 \mathrm{~m}$ CCSF-A show an inverse age-depth relationship. We interpret radiocarbon date at $0.8 \mathrm{~m}$ CCSF-A as an outlier due to the secondary deposition or coring disturbance, since the date at this interval shows an extremely older age than proximal ages.
Discussion

Riverine run-off records at Site U1461

The $\% \mathrm{~K}$ contribution to the total NGR on the shelf of NWA is interpreted to indicate the presence of fluvial-derived clays and feldspar, reflecting the 


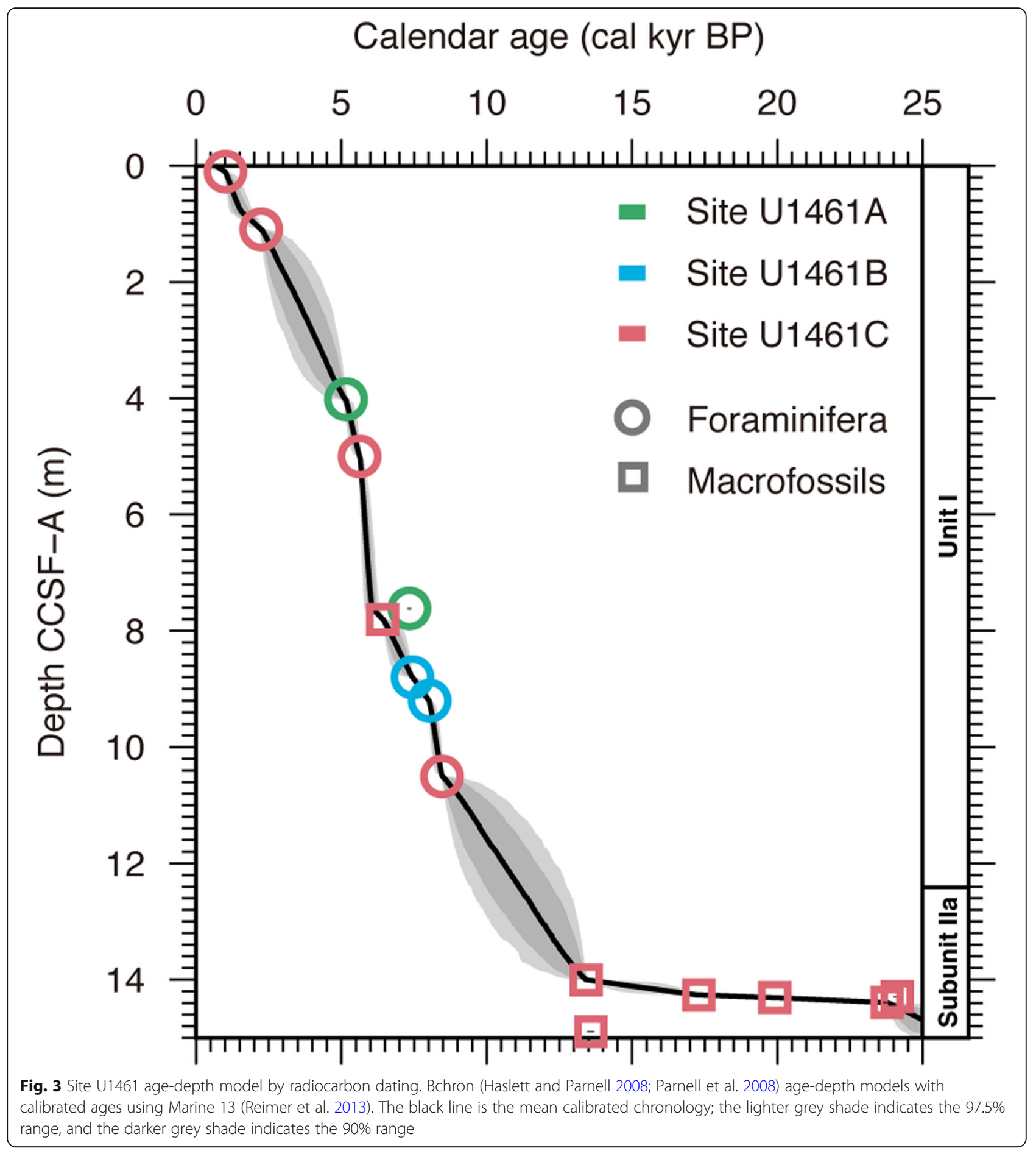

relative variability of continental moisture (Christensen et al. 2017; Groeneveld et al. 2017). The \%K from NGR data shows a similar pattern to $K$ counts derived from XRF scanning (Figs. 2 and 3). \%K variation from NGR complements the gap of $\mathrm{K}$ counts from 8.17 to 9.45 $\mathrm{m}$ CCSF-A (Fig. 2). The $\mathrm{K}$ and $\mathrm{Ti}$ counts also exhibit a similar pattern of variability (Fig. 2). Biogenic or precipitated carbonate dominates at Site U1461, with high $\mathrm{Ca}$ intensity and minor variation. We focus on the pattern of $\mathrm{K}$ normalized against $\mathrm{Ca}$. It has been previously reported that $\mathrm{K} / \mathrm{Ca}$ ratios are interpreted to reflect the variation in riverine run-off from the Australian continent in NWA (Kuhnt et al. 2015; Stuut et al. 2014). 
Variability in the Australian Summer Monsoon from the Pleistocene and the Holocene

It has been suggested that the ASM was weak or inactive during glacial periods (Wyrwoll and Miller 2001; Gallagher et al. 2014; De Deckker et al. 2014). This relative inactivity explains the extremely low sedimentation rate prior to $13.5 \mathrm{cal} \mathrm{kyr} \mathrm{BP}$ at Site U1461 (Figs. 3 and 4), suggesting a weak or absence of terrigenous input from the continent during this period.

The rapid increase in the sedimentation rate is at $13.5 \mathrm{ka}$ (Figs. 3 and 4), when the $\% \mathrm{~K}$ and $\mathrm{K} / \mathrm{Ca}$ ratios at Site U1461 remain relatively low from $\sim 13.5$ to $11.5 \mathrm{ka}$ (Fig. 4), which reveal that the ASM intensification occurred at $11.5 \mathrm{ka}$ during the transition from the Late Pleistocene to the Holocene. This intensification of the ASM corresponds to a change in lithological units from subunit IIa to unit I, marked by an increased quartz content. These increases in quartz content and \%K also suggest that the terrigenous input from the continent increased due to the enhanced ASM-driven precipitation. A marine sediment core off the Cape Range region (core Fr10/95-GC17, Fig. 1) records evidence of the ASM intensification/onset at $\sim 13 \mathrm{ka}$, which was interpreted to be due to a southward shift in the ITCZ (De Deckker et al. 2014). In addition, an increase in the chlorite content in core Fr10/95-GC17 indicates that Leeuwin Current strengthened at this time since chlorite originated from the Fortescue and De Grey rivers (Gingele et al. 2001a, 2001b), and Leeuwin Current transported these clays westward to the Cape Range region (De Deckker et al. 2014). Wyrwoll and Miller (2001) analysed the lacustrine and fluvial sediments from the Kimberley region and suggested that ASM was active after $14 \mathrm{ka}$. Similarly, peat sediments in north Kimberley record the onset of monsoonal activity after $\sim 14 \mathrm{ka}$, as evidenced by the increasing organic content in a spring (Field et al. 2017). The Kimberley region is the northern region compared with Site U1461, suggesting that the timing of onset/intensification of ASM due to the southern shift of ITCZ was earlier than Site U1461.

The transgression associated with the deglacial sea level rise shifted Site U1461 from an inner- $(0-50 \mathrm{~m})$ to a mid-ramp (50-120 $\mathrm{m}$ ) position at around $14 \mathrm{ka}$ (Fig. 4). On the modern shelf, the siliciclastic content decreases from the inner- to the mid-ramp due to the impact of storm waves and tidal currents (James et al. 2004). The observed increase in $\mathrm{K} / \mathrm{Ca}$ ratios therefore cannot be explained by a change in the depositional environment due to sea level variations.

Climate variability in the NWA during the Early Holocene Increasing $\mathrm{K} / \mathrm{Ca}$ ratios and $\% \mathrm{~K}$ from 11.5 to $8.5 \mathrm{ka}$ reveal the terrigenous input from the Australian continent (Fig. 4). Intensified precipitation during the ASM would have enhanced erosion, caused greater drainage by rivers, and increased the amount of riverine run-off bringing terrigenous components to the NWA continental shelf. Site U1461 directly receives sediments from the NWA continent through the Fortescue and De Grey rivers (James et al. 2004). The enhanced precipitation in the drainage catchment of the Fortescue and De Grey rivers is interpreted to have been caused by the southward migration of the ITCZ that began during the Early Holocene.

Stalagmite records from Ball Gown Cave (Denniston et al. 2013) (Fig. 1) reveal the trend of enhanced ASM from 11 to $8.4 \mathrm{ka}$, whereas the variation in the terrigenous input from marine sediment off the Cape Range region (Fig. 1, MD00-2361, Stuut et al. 2014) suggests an increase to $8 \mathrm{ka}$ (Fig. 4). The ITCZ southern migration shifted the rain belts to the south, explaining the increased pattern of precipitation in the NWA region. This ITCZ migration is consistent with the records from the latitudinal cores across the Timor Sea (Kuhnt et al. 2015).

\section{Climate variability in the NWA after the Early Holocene}

The decrease in the $\mathrm{K} / \mathrm{Ca}$ ratios and $\% \mathrm{~K}$ content revealed a reduction in terrigenous input after $8.5 \mathrm{ka}$ at Site U1461 (Fig. 4), indicating a weakening of erosion and riverine run-off in the drainage area due to reduced precipitation. The northern migration of the ITCZ moved the rain belt away from NWA after $8.5 \mathrm{ka}$, while the northern cores across the Timor Sea show the shift to dry condition between 8.1 and $7.3 \mathrm{ka}$ (Kuhnt et al. 2015). However, this apparent dry shift is not strongly observed in the record from the Cape Range region (Fig. 4, Stuut et al. 2014). The stronger covariation between the record at Site 1461 with continental archives may be related to its proximal position at the continental shelf, which is directly influenced by the continental climate variability in NWA.

\section{Conclusions}

The IODP Expedition 356 cored the upper slope to the outer shelf carbonates at Site U1461 at a present-day latitude of $20^{\circ} \mathrm{S}$. The site is close to the Australian coast, which makes Site U1461 ideally located to record the ASM intensity. Indeed, this area has received fluvially sourced siliciclastic sediment over the last five million years. The focus of this work is the upper $14 \mathrm{~m}$, where a near-complete 14,000-years record of the variability of the ASM is preserved. Shipboard NGR (\%K) and XRF-derived K/Ca ratios chart a detailed LGM to Holocene record of terrigenous input through riverine run-off.

Increased \% $\mathrm{K}$ and $\mathrm{K} / \mathrm{Ca}$ ratios from 11.5 to $8.5 \mathrm{ka}$ reveal the enhanced ASM precipitation due to the ITCZ 


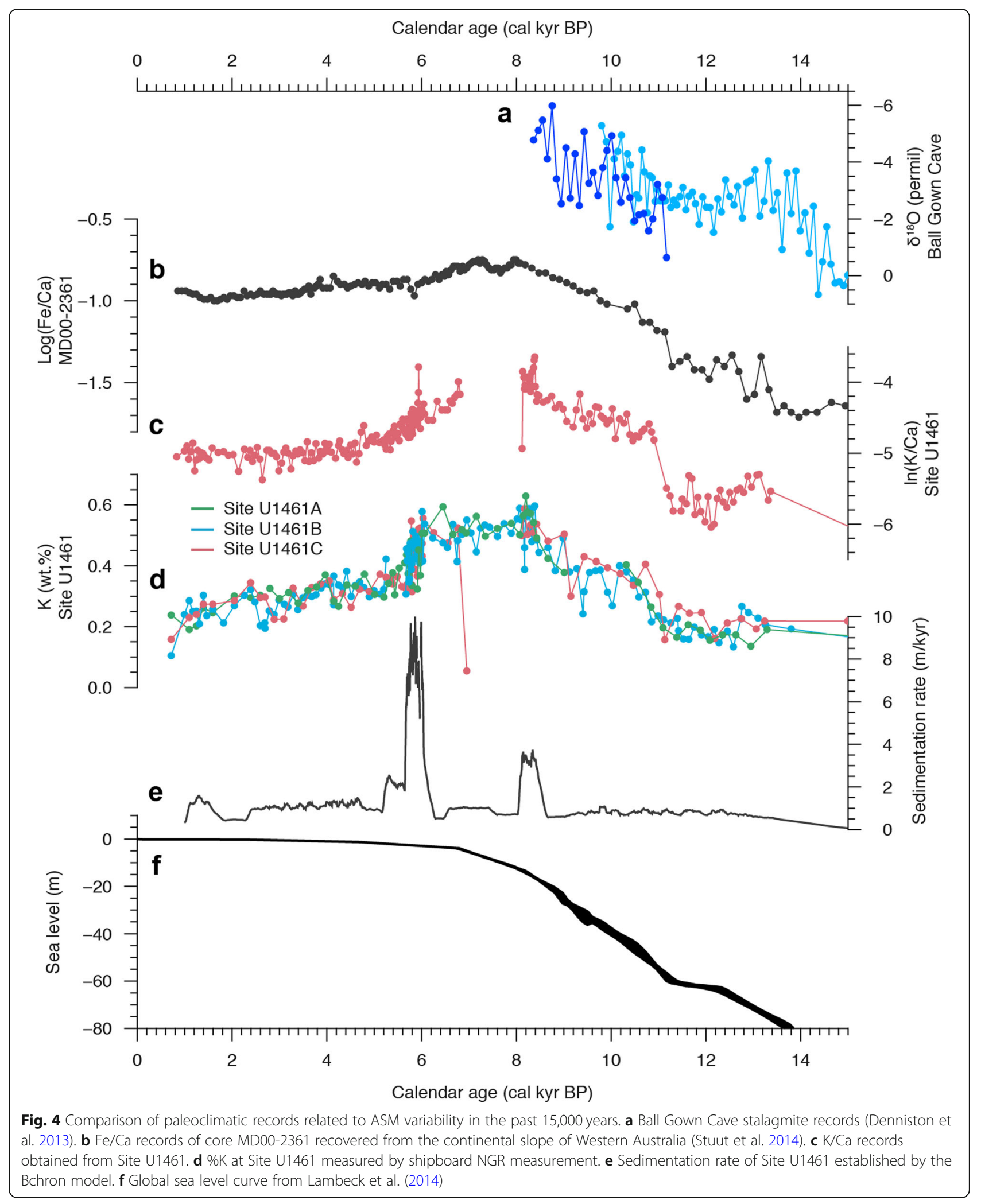


southward shift. This increased precipitation trend is also observed in a speleothem record from Ball Gown Cave and sediment records from the Cape Range region. This trend is caused by the southern shift of the ITCZ, which brings the seasonal rain belt to the NWA. A reduction of $\% \mathrm{~K}$ and $\mathrm{K} / \mathrm{Ca}$ ratios after $8.5 \mathrm{ka}$ is interpreted as a shift to more arid conditions in the NWA, caused by the northward shift of the ITCZ.

\section{Abbreviations}

ASM: Australian Summer Monsoon; IODP: International Ocean Discovery Program; ITCZ: Intertropical Convergence Zone; LGM: Last Glacial Maximum; NGR: Natural gamma radiation; NWA: Northwestern Australia

\section{Acknowledgements}

This study used samples and data from the International Ocean Discovery Program Expedition 356 Indonesian Throughflow. We truly appreciate the members of this expedition, including the JOIDES Resolution Science Operator and the Siem Offshore crew and the Expedition 356 science party, and Drs. T. Aze, C. Sawada, and Y. Miyairi for laboratory assistance. We also thank the handling editor Ken Ikehara and the two anonymous reviewers whose comments greatly improved the manuscript.

\section{Funding}

Funding was provided by the Australian IODP office and the ARC Basins Genesis Hub (IH130200012) to S.J.G., the Japan Society for the Promotion of Science (JSPS) KAKENHI (16J04542) to T.I. and KAKENHI (15KK0151, 17H01168) to Y.Y., the DFG (German Science Foundation, Project 320220579) to L.R., NSF - United States Science Support Program (USSSP), OCE-1450528 for C.M., and the Deutsche Forschungsgemeinschaft (VL96/1-1) to D.D.V.. This work is part of a DAAD project DANA between S.J.G. and D.D.V.. The production of this paper was supported by a National Institute of Polar Research publication subsidy.

\section{Availability of data and materials}

Radiocarbon date are available in Table 1. Please contact author for other data requests such as NGR and XRF.

\section{Authors' contributions}

$\mathrm{TI}$ carried out this research with input from the co-authors. CMM and LR conducted the XRF core scanning, and $Y Y$ proceeded with the radiocarbon measurements. YY, CMM, LR, DDV, and SJG contributed to the discussions and improved the manuscripts. TI, CMM, LR, DDV, and SJG were part of the IODP Expedition 356 Science Party. All authors approved the final manuscript.

\section{Competing interests}

The authors declare that they have no competing interests.

\section{Publisher's Note}

Springer Nature remains neutral with regard to jurisdictional claims in published maps and institutional affiliations.

\section{Author details}

${ }^{1}$ National Institute of Polar Research, Tokyo, Japan. ${ }^{2}$ Atmosphere and Ocean Research Institute, The University of Tokyo, Chiba, Japan. ${ }^{3}$ Department of Earth and Planetary Science, Graduate School of Science, The University of Tokyo, Tokyo, Japan. ${ }^{4}$ Energy and Mineral Resources Group, Geological Institute, RWTH Aachen University, Aachen, Germany. ${ }^{5}$ School of Earth and Environmental Sciences, Queens College (C.U.N.Y.), Flushing, New York, USA. ${ }^{6}$ MARUM-Center for Marine and Environmental Sciences, University of Bremen, Bremen, Germany. ${ }^{7}$ School of Earth Sciences, University of Melbourne, Melbourne, Victoria, Australia. ${ }^{8}$ Present Address: Institute of Geosciences, CAU Kiel University, Kiel, Germany.
}

Received: 8 August 2018 Accepted: 21 January 2019

Published online: 13 February 2019

\section{References}

Amante C, Eakins BW (2009) ETOPO1 1 arc-minute global relief model: procedures, data sources and analysis. NOAA Technical Memorandum NESDIS NGDC-24. National Geophysical Data Center, NOAA.

Ayliffe LK, Gagan MK, Zhao J, Drysdale RN, Hellstrom JC, Hantoro WS, Griffiths ML, Scott-Gagan H, Pierre ES, Cowley JA, Suwargadi BW (2013) Rapid interhemispheric climate links via the Australasian monsoon during the last deglaciation. Nat Commun 4:1-6.

Betzler C, Eberli GP, Lüdmann T, Reolid J, Kroon D, Reijmer JJG, Swart PK, Wright J, Young JR, Alvarez-Zarikian C, Alonso-García M, Bialik OM, Blättler CL, Guo JA, Haffen S, Horozal S, Inoue M, Jovane L, Lanci L, Laya JC, Hui Mee AL, Nakakuni M, Nath BN, Niino K, Petruny LM, Pratiwi SD, Slagle AL, Sloss CR, Su X, Yao Z (2017) Refinement of Miocene sea level and monsoon events from the sedimentary archive of the Maldives (Indian Ocean). Prog Earth Planet Sci 5:5.

Bowman GM (1985) Oceanic reservoir correction for marine radiocarbon dates from northwestern Australia. Aust Archaeol 20:58-67.

Christensen BA, Renema W, Henderiks J, De Vleeschouwer D, Groeneveld J, Castañeda IS, Reuning L, Bagus K, Auer G, Ishiwa T, McHugh CM, Gallagher SJ, Fulthorpe CS, IODP Expedition 356 Scientists (2017) Indonesian Throughflow drove Australian climate from humid Pliocene to arid Pleistocene. Geophys Res Lett 44:6914-6925.

De Deckker P (2016) The Indo-Pacific Warm Pool: critical to world oceanography and world climate. Geosci Lett 3:1-12.

De Deckker P, Barrows T, Rogers J (2014) Land-sea correlations in the Australian region: post-glacial onset of the monsoon in northwestern Western Australia. Quat Sci Rev 105:181-194.

De Vleeschouwer D, Dunlea AG, Auer G, Anderson CH, Brumsack H, de Loach A, Gurnis M, Huh Y, Ishiwa T, Jang K, Komiz MA, Marz C, Schnetger B, Murray RW, Palike H, Expedition 356 Shipboard Scientists (2017) Quantifying K, U, and Th contents of marine sediments using shipboard natural gamma radiation spectra measured on DV JOIDES Resolution. Geochem Geophys Geosyst 18:1-12.

Denniston RF, Wyrwoll KH, Asmerom Y, Polyak VJ, Humphreys WF, Cugley J, Woods D, LaPointe Z, Peota J, Greaves E (2013) North Atlantic forcing of millennial-scale Indo-Australian monsoon dynamics during the Last Glacial period. Quat Sci Rev 72:159-168.

Di Nezio PN, Tierney JE (2013) The effect of sea level on glacial Indo-Pacific climate. Nat Geosci 6:485-491.

Eroglu D, McRobie FH, Ozken I, Stemler T, Wyrwoll KH, Breitenbach SFM, Marwan N, Kurths J (2016) See-saw relationship of the Holocene East Asian-Australian summer monsoon. Nat Commun 7:1-7.

Field E, McGowan HA, Moss PT, Marx SK (2017) A Late Quaternary record of monsoon variability in the northwest Kimberley, Australia. Quat Int 449: 119-135.

Gagan MK, Hendy EJ, Haberle SG, Hantoro WS (2004) Post-glacial evolution of the Indo-Pacific Warm Pool and El Niño-Southern oscillation. Quat Int 118-119: 127-143.

Gallagher SJ, Fulthorpe CS, Bogus KA, Auer G, Baranwal S, Castañeda IS, Christensen BA, De Vleeschouwer D, Franco DR, Groeneveld J, Gurnis M, Haller C, He Y, Henderiks J, Himmler T, Ishiwa T, Iwatani H, Jatiningrum RS, Kominz MA, Korpanty CA, Lee EY, Levin E, Mamo BL, McGregor HV, McHugh CM, Petrick BF, Potts DC, Rastegar Lari A, Renema W, Reuning L, Takayanagi H, Zhang W (2017a) Site U1461. Proc Int Ocean Discov Program 356:1-65.

Gallagher SJ, Fulthorpe CS, Bogus KA, Auer G, Baranwal S, Castañeda IS, Christensen BA, De Vleeschouwer D, Franco DR, Groeneveld J, Gurnis M, Haller C, He Y, Henderiks J, Himmler T, Ishiwa T, Iwatani H, Jatiningrum RS, Kominz MA, Korpanty CA, Lee EY, Levin E, Mamo BL, McGregor HV, McHugh CM, Petrick BF, Potts DC, Rastegar Lari A, Renema W, Reuning L, Takayanagi H, Zhang W (2017b) Expedition 356 methods. Proc Int Ocean Discov Program 356:1-37.

Gallagher SJ, Fulthorpe CS, Bogus KA, Expedition 356 Scientists (2015) Expedition 356 preliminary report: Indonesian Throughflow. International Ocean Discovery Program.

Gallagher SJ, Wallace MW, Hoiles PW, Southwood JM (2014) Seismic and stratigraphic evidence for reef expansion and onset of aridity on the Northwest Shelf of Australia during the Pleistocene. Mar Pet Geol 57 $470-481$. 
Gallagher SJ, Wallace MW, Leong LC, Kinna B, Bye JAT, Akimoto K, Torii M (2009) Neogene history of the Indo-Pacific Warm Pool, Kuroshio and Leeuwin currents. Paleoceanography 24:1-27.

Gingele FX, De Deckker P, Hillenbrand CD (2001a) Clay mineral distribution in surface sediments between Indonesia and NW Australia-source and transport by ocean currents. Mar Geol 179:135-146.

Gingele FX, De Deckker P, Hillenbrand CD (2001b) Late Quaternary fluctuations of the Leeuwin Current and palaeoclimates on the adjacent land masses: clay mineral evidence. Aust J Earth Sci 48:867-874.

Groeneveld J, Henderiks J, Renema W, McHugh CM, De Vleeschouwer D, Christensen BA, Fulthorpe CS, Reuning L, Gallagher SJ, Borgus K, Auer G, Ishiwa T, Expedition 356 Scientists (2017) Australian shelf sediments reveal shifts in Miocene Southern Hemisphere westerlies. Sci Adv 3:1602567.

Haslett J, Parnell A (2008) A simple monotone process with application to radiocarbon-dated depth chronologies. J R Stat Soc: Ser C: Appl Stat 57: 399-418.

Huffman GJ, Adler RF, Chang A, Ferraro R, Gruber A, Janowiak J, McNab A, Rudolf B, Schneider U (1997) The Global Precipitation Climatology Project (GPCP) Combined Precipitation Dataset. Bull Am Meteorol Soc 78:5-20.

Ishiwa T, Yokoyama Y, Miyairi Y, Ikehara M, Obrochta S (2016) Sedimentary environmental change induced from Late Quaternary sea-level change in the Bonaparte Gulf, northwestern Australia. Geosci Lett 3:33.

James NP, Bone Y, Kyser TK, Dix GR, Collins LB (2004) The importance of changing oceanography in controlling late Quaternary carbonate sedimentation on a high-energy, tropical, oceanic ramp: North-Western Australia. Sedimentology 51:1179-1205

Kido Y, Koshikawa T, Tada R (2006) Rapid and quantitative major element analysis method for wet fine-grained sediments using an XRF microscanner. Mar Geol 229:209-225.

Kuhnt W, Holbourn A, Xu J, Opdyke B, De Deckker P, Röhl U, Mudelsee M (2015) Southern Hemisphere control on Australian monsoon variability during the late deglaciation and Holocene. Nat Commun 6:5916.

Lambeck K, Rouby H, Purcell A, Sun Y, Sambridge M (2014) Sea level and global ice volumes from the Last Glacial Maximum to the Holocene. Proc Natl Acad Sci 111:15296-15303.

Mohtadi M, Oppo DW, Steinke S, Stuut JBW, De Pol-Holz R, Hebbeln D, Lückge A (2011) Glacial to Holocene swings of the Australian - Indonesian monsoon. Nat Geosci 4:540-544

Nakamura A, Yokoyama Y, Maemoku H, Yagi H, Okamura M, Matsuoka H, Miyake N, Osada T, Pani Adhikari D, Dangol V, Ikehara M, Miyairi Y, Matsuzaki H (2016) Weak monsoon event at 4.2 ka recorded in sediment from Lake Rara, Himalayas. Quat Int 397:349-359.

O'Connor S, Ulm S, Fallon SJ, Barham A, Loch I (2010) Pre-bomb marine reservoir variability in the Kimberley region, Western Australia. Radiocarbon 52:1158-1165.

Parnell AC, Haslett J, Allen JRM, Buck CE, Huntley B (2008) A flexible approach to assessing synchroneity of past events using Bayesian reconstructions of sedimentation history. Quat Sci Rev 27:1872-1885.

Reimer PJ, Bard E, Bayliss A, Beck JW, Blackwell PG, Ramsey CB, Buck CE, Cheng H, Edwards RL, Friedrich M, Grootes PM, Guilderson TP, Haflidason H, Hajdas I, Hatte C, Heaton TJ, Hoffmann DL, Hogg AG, Hughen KA, Kaiser KF, Kromer B, Manning SW, Niu M, Reimer RW, Richards DA, Scott EM, Southon JR, Staff RA, Turney CSM, van der Plicht J (2013) Intcal13 and marine13 radiocarbon age calibration curves 0-50,000 years cal bp. Radiocarbon 55:1869-1887.

Stuut JBW, Temmesfeld F, De Deckker P (2014) A 550 ka record of aeolian activity near North West Cape, Australia: inferences from grain-size distributions and bulk chemistry of SE Indian Ocean deep-sea sediments. Quat Sci Rev 83:83-94.

Tada R, Zheng H, Clift PD (2016) Evolution and variability of the Asian monsoon and its potential linkage with uplift of the Himalaya and Tibetan plateau. Prog Earth Planet Sci 3:4.

Wang YJ, Cheng H, Edwards RL, An ZS, Wu JY, Shen C-C, Dorale JA (2001) A high-resolution absolute-dated Late Pleistocene monsoon record from Hulu Cave, China. Science 294:2345-2348.

Wessel P, Smith WHF (1996) A global self-consistent, hierarchical, high-resolution shoreline database. J Geophys Res 101:8741-8743.

Wessel P, Smith WHF, Scharroo R, Luis JF, Wobbe F (2013) Generic mapping tools: improved version released. EOS Trans AGU 94:409-410.

Wyrwoll KH, Miller GH (2001) Initiation of the Australian summer monsoon 14,000 years ago. Quat Int 82:119-128.

Yokoyama Y, Anderson JB, Yamane M, Simkins LM, Miyairi Y, Yamazaki T, Koizumi M, Suga H, Kusahara K, Prothro L, Hasumi H, Southon JR, Ohkouchi N (2016)
Widespread collapse of the Ross Ice Shelf during the Late Holocene. Proc Natl Acad Sci 113:2354-2359.

Yokoyama Y, Miyairi Y, Matsuzaki H, Tsunomori F (2007) Relation between acid dissolution time in the vacuum test tube and time required for graphitization for AMS target preparation. Nucl Instrum Meth Phys 259 330-334.

\section{Submit your manuscript to a SpringerOpen ${ }^{\circ}$ journal and benefit from:}

- Convenient online submission

- Rigorous peer review

- Open access: articles freely available online

- High visibility within the field

- Retaining the copyright to your article

Submit your next manuscript at $\boldsymbol{\nabla}$ springeropen.com 